\title{
Effect of Temperature on Oxygen Profiles and Denitrification Rates in Freshwater Sediments
}

\author{
Jeroen J. M. de Klein ${ }^{1}$ (1) • Ciska C. Overbeek ${ }^{2,3}$ • Christian Juncher Jørgensen ${ }^{4,5}$ • \\ Annelies J. Veraart ${ }^{6}$
}

Received: 23 November 2016 / Accepted: 5 July 2017 / Published online: 18 July 2017

(C) The Author(s) 2017. This article is an open access publication

\begin{abstract}
Vegetated ditches and wetlands are important sites for nutrient removal in agricultural catchments. About half of the influx of inorganic nitrogen can be removed from these ecosystems by denitrification. Previous studies have shown that denitrification in aquatic ecosystems is strongly temperature dependent, resulting from temperature-dependent oxygen availability. Here, we study short-term temperature effects on sediment oxygen demand (SOD) and the maximum depth of oxygen penetration into the sediment $(\mathrm{Z})$, in relation to overall denitrification rates. We set up sixteen wetland microcosms at four different temperatures $\left(11-25^{\circ} \mathrm{C}\right)$, in which we determined SOD and $\mathrm{Z}$ from sediment oxygen microprofiles. Denitrification rates were measured using ${ }^{15} \mathrm{~N}$-labeling, analysed by membrane inlet mass
\end{abstract}

Electronic supplementary material The online version of this article (doi:10.1007/s13157-017-0933-1) contains supplementary material, which is available to authorized users.

Jeroen J. M. de Klein

Jeroen.deklein@wur.nl

1 Department of Aquatic Ecology and Water Quality Management, Wageningen University, Wageningen, the Netherlands

2 Department of Aquatic Environmental Ecology, University of Amsterdam, Amsterdam, the Netherlands

3 Present address: Nelen and Schuurmans Consultancy, Utrecht, the Netherlands

4 Department of Geosciences and Natural Resource Management, Section of Geography, University of Copenhagen, Copenhagen, Denmark

5 Present address: Force Technology, Brøndby, Denmark

6 Department of Microbial Ecology, Netherlands Institute of Ecology (NIOO-KNAW), Wageningen, The Netherlands spectrometry. Temperature strongly affected sediment oxygen dynamics. SOD exponentially rose with temperature, ranging from 0.37 to $1.53 \mathrm{~g} \mathrm{~m}^{-2} \mathrm{~d}^{-1}\left(\mathrm{Q}_{10}=2.4\right)$. Correspondingly, warming led to shallower oxygen penetration into the sediment, ranging from 4.12 to $2.08 \mathrm{~mm}$. Denitrification rates increased with warming $\left(\mathrm{Q}_{10}=2.6\right)$, ranging from 8.4 to $86 \mu \mathrm{mol} \mathrm{N} \mathrm{m} \mathrm{N}^{-2} \mathrm{~h}^{-1}$. The results of this short-term experiment confirm the potential increase of denitrification with rising temperature, promoted by lower oxygen availability in the top layer of the sediment, which supports the understanding of denitrification variability in freshwaters.

Keywords Agricultural wetland · Biogeochemistry $\cdot$ Climate change $\cdot$ Denitrification $\cdot$ Membrane inlet mass spectrometry (MIMS) $\cdot$ Nitrogen cycling

\section{Introduction}

Climate change is projected to lead to an increase in the average global temperature of more than 2 degrees Celsius by the end of the twenty-first century (IPCC 2014). At the same time, nitrogen pollution is expected to increase, due to intensification of agricultural and industrial activities. This can amplify eutrophication effects in freshwater and coastal habitats, and increase the emission of the potent greenhouse gas $\mathrm{N}_{2} \mathrm{O}$ (Erisman et al. 2013; Stein and Klotz 2016). Currently, the altered flow of reactive nitrogen into ecosystems is already one of the most pressing global environmental issues (Steffen et al. 2015). Freshwater ecosystems, such as wetlands and shallow lakes, can buffer effects of nitrogen pollution by transforming nitrogen in their sediments, water column, and biota (Saunders and Kalff 2001). Vegetated ditches 
in wetland areas act as nitrogen filters in the agricultural landscape, removing a large proportion of nitrogen before they drain into connected rivers and lakes (de Klein 2008; Veraart et al. 2016). These ditches are common freshwater ecosystems in low-lying agricultural areas and peatlands, constituting natural sediment and bank vegetation similar to wetlands (Herzon and Helenius 2008). In the Netherlands, ditches are an important ecosystem type, covering an area similar to that of shallow lakes or rivers. Their tight terrestrial-aquatic coupling makes them biogeochemical hotspots. In these ecosystems, denitrification - the microbial conversion of nitrate $\left(\mathrm{NO}_{3}{ }^{-}\right)$or nitrite $\left(\mathrm{NO}_{2}{ }^{-}\right)$via nitric oxide (NO) and nitrous oxide $\left(\mathrm{N}_{2} \mathrm{O}\right)$ to dinitrogen gas $\left(\mathrm{N}_{2}\right)$ - can remove more than half of the nitrogen influxes, making it a crucial process counteracting eutrophication (de Klein and Koelmans 2011; Veraart 2012). However, because denitrification on average produces $1-5 \%$ of its gaseous end product in the form of $\mathrm{N}_{2} \mathrm{O}$, enhanced denitrification rates can also pose a strong, yet understudied, positive feedback on global warming (Veraart et al. 2011; Hanke et al. 2015).

Denitrification is a major sink for inorganic nitrogen in freshwater ecosystems, however, several studies in the past two decades have demonstrated that anaerobic ammonium oxidation (anammox) can also significantly contribute to N removal (Risgaard-Petersen et al. 2003; Seitzinger et al. 2006). Denitrification is carried out by a wide range of microorganisms, most of which are facultative anaerobes, which will only denitrify once oxygen becomes limiting (Knowles 1982). Denitrifiers use organic carbon (canonical heterotrophic denitrification), sulphide, or hydrogen (chemolithoautotrophic denitrification) as an electron donor (Burgin et al. 2012). Or, in the special case of methane-oxidation dependent denitrification, methane reduction and oxidation are coupled to nitrite dismutation (Ettwig et al. 2010; Stein and Klotz 2016). Because of the prevailing nitrate and oxygen concentrations, freshwater denitrification activities are often highest at the oxic-anoxic boundary layer in the sediment, in particular at sites where the diffusion path of nitrate from the overlying water to the anoxic denitrification zone is small, i.e. when oxygen penetration into the sediment is shallow (Risgaard-Pedersen et al. 1994). Here, denitrification can be tightly coupled to nitrification, the aerobic oxidation of ammonium to nitrate, which takes place in the oxygenated top layer of the sediment (Seitzinger et al. 2006). The strength of this coupling depends on nitrogen availability and presence of oxic-anoxic interface. Thus, sediment oxygen concentrations, sediment oxygen demand and associated oxygen penetration depth will be important drivers of denitrification.

All enzymatic reactions are affected by warming, both as a direct effect on enzyme activity and by indirect temperature effects on substrate availability. Recent studies indicate that within freshwater sediments and phototrophic biofilms, warming can strongly increase denitrification rates (Bonnett et al. 2013), due to temperature-regulated oxygen concentrations (Veraart et al. 2011; Bouletreau et al. 2012). However, in these studies oxygen concentrations were measured in the water column, whereas most denitrification takes place in the sediment.

The zonation of respiratory organic matter degradation and denitrification in a sediment profile is strongly linked to the oxygen concentration at a given depth (Rysgaard et al. 1994; Seitzinger 1994). Sediment oxygen demand arises from respiration, most notably aerobic degradation of organic material. Warming can affect sediment oxygen demand and oxygen penetration depth in different ways. On one hand, it can lower oxygen concentrations by reducing oxygen solubility and by more strongly enhancing respiration rates relative to photosynthesis (Hancke and Glud 2004; Allen et al. 2005; Yvon-Durocher et al. 2010; Bouletreau et al. 2012). On the other hand, effective diffusion rates of oxygen into the sediment will also increase with rising temperature (Elberling and Damgaard 2001). Therefore, temperature effects on sediment oxygen dynamics are expected to vary between sediments, depending on carbon substrate and electron availability and physical sediment structure.

Because sediment oxygen dynamics are driven by several biotic and abiotic processes which each have their own temperature response, effects of increased temperatures on sediment oxygen demand, oxygen penetration depth, and denitrification are not straightforward. To further unravel the complexity of these interacting processes we determine the short-term effects of temperature on oxygen availability and uptake in ditch sediments. To this end, we measured oxygen microprofiles in the top layer of the sediment and denitrification rates in laboratory microcosms at $11,16,21$ and $25{ }^{\circ} \mathrm{C}$. From the oxygen microprofiles we determine the oxygen penetration depth $(Z)$ and the areal respiration rate, expressed as Sediment Oxygen Demand (SOD), by fitting an oxygen flux model to the data. The results of this analysis can contribute to a better understanding of the carbon and nitrogen cycle in ditches, which are important ecosystems in agricultural environments.

\section{Materials and Methods}

\section{Experimental Setup}

We used a microcosm set-up to create an intermediate system between core incubations and in-situ measurements, as larger and less disturbed systems may better 
resemble environmental conditions. Sixteen microcosms (V: 9 1, h: $26 \mathrm{~cm}$, top Ø $24.7 \mathrm{~cm}$, bottom Ø $18.5 \mathrm{~cm}$ ) were filled with 21 sieved (mesh size $2 \mathrm{~mm}$ ), homogenised sediment and 61 Smart and Barko medium (Smart and Barko 1985), containing $1 \mathrm{mg} 1^{-1}$ nitrogen $\left(\mathrm{NaNO}_{3}-\mathrm{N}\right)$ and $0.19 \mathrm{mg} \mathrm{l}^{-1}$ phosphorus $\left(\mathrm{K}_{2} \mathrm{HPO}_{4}-\mathrm{P}\right)$, to simulate nutrient concentrations in agricultural drainage ditches (Veraart et al. 2016). The medium contained no additional organic carbon. The sediment originated from a eutrophic drainage ditch bordering an experimental farm in Wageningen, the Netherlands $\left(51^{\circ} 59^{\prime} 16.10^{\prime \prime} \mathrm{N}, 5^{\circ} 39^{\prime}\right.$ $02.80^{\prime \prime} \mathrm{E}$, crop rotation), and contained approximately $8 \%$ organic matter. This ditch is representative of agricultural drainage ditches in the Netherlands and was selected because of confirmed high denitrification potential (Veraart et al. 2016). The microcosms were pre-incubated for 7 weeks in a water bath at $17.5^{\circ} \mathrm{C}$, at a $12 \mathrm{~h} / 12 \mathrm{~h}$ light/ dark regime, to allow for stabilization of sediment microbial communities after relocation to the lab. The water bath was only used to regulate temperature, each microcosm had its own headspace of overlying water. Headspaces were not mixed or artificially aerated, but left to equilibrate with the atmosphere. Pre-incubation was not yet done at variable temperatures to keep the microcosms comparable at the start. Water loss by evaporation was compensated for by weekly replenishing the microcosms with deionised water. At the same time nitrate was resupplied to the microcosms, adding $0.1 \mathrm{mg} \mathrm{l}^{-1} \mathrm{NO}_{3}-\mathrm{N}$, to maintain summer nitrogen concentrations, which tend to be nitrogen limited, though experiencing occasional nitrogen pulses. After the incubation period, the microcosms were placed at four different water temperatures $\left(11,16,21\right.$ and $\left.25^{\circ} \mathrm{C}\right)$, with four replicates per temperature treatment.

\section{Oxygen Microprofiles}

Microprofiles of oxygen concentration in the sediment were measured 1 day after placing the microcosms at the experimental temperature to allow for equilibration of sediment conditions. Sediment oxygen microprofiles were measured using a Unisense microelectrode equipped with a high-precision micromanipulator (Unisense, Aarhus, Denmark). Because we expect an important role of the balance between respiration and photosynthesis on both oxygen dynamics and denitrification, mimicking the actual conditions in the ditches, oxygen profiles were measured after a period of 4-8 h of light irradiance (ca. $120 \mu \mathrm{mol}$ photons $\mathrm{m}^{-2} \mathrm{~s}^{-1}$ ). Overlying water in the microcosms was not stirred, nor artificially aerated. Oxygen concentrations were recorded at a $100 \mu \mathrm{m}$ to $1 \mathrm{~mm}$ interval, taken over a total depth of $38 \mathrm{~mm}$, keeping the sensor tip at each depth for around $30 \mathrm{~s}$. From the obtained

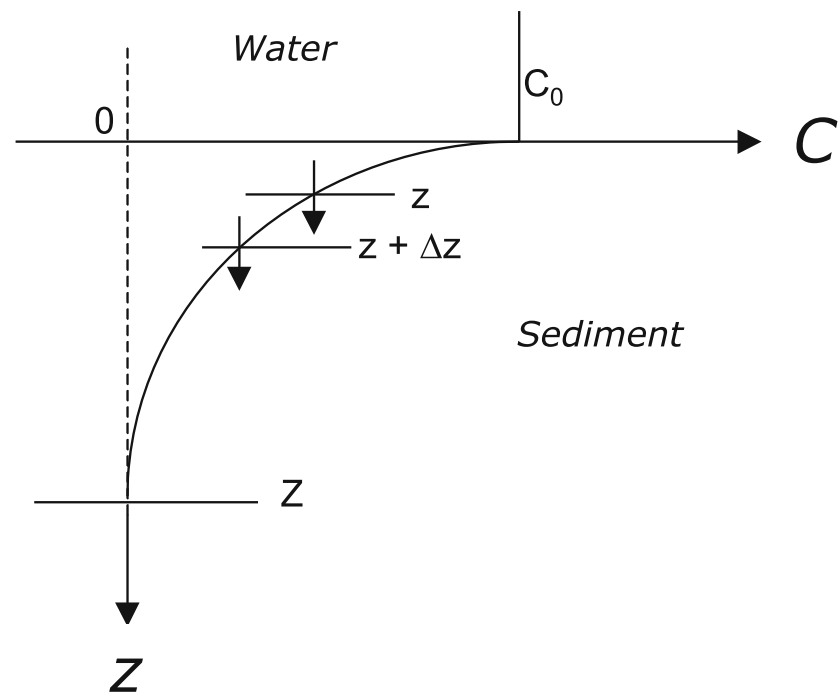

Fig. 1 Oxygen concentration $(C)$ at the water-sediment interface plotted against depth (z). Starting from a water column concentration $\left(\mathrm{C}_{0}\right)$ oxygen decreases to zero at the oxygen penetration depth $(\mathrm{Z})$

microprofiles two major characteristics were determined: sediment oxygen demand (SOD) and the oxygen penetration depth $(Z)$. This was done by calibrating SOD and Z for all individual profiles to fit a theoretical oxygen diffusion model (Fig. 1).

Assuming that only molecular diffusion is responsible for the supply of oxygen, a mass balance for a thin horizontal slice of sediment with a unit surface area yields:

$\left.D \frac{d C}{d z}\right|_{z}-\left.D \frac{d C}{d z}\right|_{z+\Delta z}=R \Delta z$

$D \frac{d^{2} C}{d z^{2}}-R=0$

with

$D \quad D_{m}$.

C dissolved oxygen concentration $\left(\mathrm{g} \mathrm{m}^{-3}\right)$.

$z \quad$ depth (m).

$R$ the volumetric respiration rate of the sediment $\left(\mathrm{g} \mathrm{m}^{-3}\right.$ $\left.\mathrm{d}^{-1}\right)$.

$D \quad$ apparent diffusion coefficient $\left(\mathrm{m}^{2} \mathrm{~d}^{-1}\right)$.

$D_{m}$ molecular diffusion coefficient $\left(\mathrm{m}^{2} \mathrm{~d}^{-1}\right)$. sediment porosity (-).

Double integration of Eq. 2 (see Supporting Information) gives:

$C=\frac{R}{2 D}(Z-z)^{2}$

which is a parabolic profile for the concentration $C$ with depth $z$. Using the condition that at $\mathrm{z}=0, \mathrm{C}=\mathrm{C}_{0}$ an expression for 
the oxygen penetration depth $Z$ and SOD can be derived from Eq. 3:

$Z=\sqrt{\frac{2 C_{0} D}{R}}$

$S O D=R^{*} Z=\sqrt{2 C_{0} D R}$

The molecular diffusion coefficient for oxygen in water $\left(D_{m}\right)$ is $1.18^{*} 10^{-4}, 1.36^{*} 10^{-4}, 1.55^{*} 10^{-4}$ and $1.72 * 10^{-4} \mathrm{~m}^{2}$ $\mathrm{d}^{-1}$ at $11,16,21$ and $25^{\circ} \mathrm{C}$, respectively (Han and Bartels 1996). Porosity of the cores was estimated from dry matter and organic matter content (Avnimelech et al. 2001). Average porosity showed to be $0.84 \pm 0.09$ (-).

For all individual cores the values for $R, Z$ and the relative position of the sediment-water-interface $(\mathrm{z}=0)$ were derived by fitting Eq. 3 to the measured oxygen profiles. Parameter calibration was done by the solver in MS Excel, by minimising the sum of squares. For the model fitting we used the condition, that:

above sediment-water interface:

from $\mathrm{z}=0$ to $\mathrm{z}=\mathrm{Z}$ :

$C=C_{0}\left(=Z^{2} R / 2 D\right)$

if $\mathrm{Z}>\mathrm{Z}: \mathrm{C}=0$

Finally, $S O D$ was calculated from $R$ and $Z$ (Eq. 5).

\section{Denitrification}

Denitrification rates were measured after $48 \mathrm{~h}$ of incubation at the experimental temperature $\left(11,16,21\right.$ or $\left.25^{\circ} \mathrm{C}\right)$, after $4 \mathrm{~h}$ of light irradiance. For these measurements the microcosms were closed with airtight lids under the water surface. The water under the lids was enriched with ${ }^{15} \mathrm{~N} \mathrm{NaNO}_{3}, 98$ atom \%) to a concentration of $1 \mathrm{mg}$ ${ }^{15} \mathrm{~N}^{-1}$, through an airtight septum and gently mixed using an airtight glass syringe. Water samples were taken in duplicate through the septum, $15 \mathrm{~min}$ and $3 \mathrm{~h}$ after addition of the ${ }^{15} \mathrm{~N}$ labelled nitrate. The samples were stored in $12 \mathrm{ml}$ exetainers until analysis (Labco, High Wycombe, United Kingdom). Exetainers contained $240 \mu \mathrm{l}(50 \% \mathrm{w}: \mathrm{v}) \mathrm{ZnCl}_{2}$ solution to stop biological processes (Dalsgaard 2000). Samples were stored in the dark at room temperature, and were kept under water to prevent exchange of gasses with the atmosphere. Isotopic ratios of the produced $\mathrm{N}_{2}$ were measured by membrane inlet mass spectrometry (MIMS), using an OmniStar Gas Analysis System (Pfeiffer Vacuum, Asslar, Germany), equipped with a quadrupole QMS 200 mass spectrometer with Channeltron detector (Burle Industries), with inlet described by Schrier-Uijl et al. (2011). Additionally, a cryogenic trap $\left(-196{ }^{\circ} \mathrm{C}\right)$ was installed before the MS inlet to remove water vapour and other gasses that could interfere with measurement of $\mathrm{N}_{2}$ gas (Kana et al. 1994;
An et al. 2001). Ratios between measured gasses and argon in air-saturated water were used to standardise isotopic ratios and correct for measurement variability, assuming argon concentrations would remain at saturation level during the measurements. Next, microcosm denitrification rates were calculated from the increase in ${ }^{29} \mathrm{~N}_{2}$ and ${ }^{30} \mathrm{~N}_{2}$ gas concentration over time, measured in the overlying water. The production of unlabelled ${ }^{28} \mathrm{~N}_{2}$ is calculated from the ratio between ${ }^{29} \mathrm{~N}_{2}$ and ${ }^{30} \mathrm{~N}_{2}$ production (Nielsen 1992). The relative contribution of nitrificationdenitrification and anammox to the $\mathrm{N}_{2}$-production was evaluated from the ratio of the gasses (Risgaard-Petersen et al. 2003). Note that the nitrogen addition needed for this type of denitrification measurements restricts its validity to non-nitrogen limited systems. Additionally, the addition of labelled nitrate as the main nitrogen source for denitrification restricts our conclusions to effects on denitrification, reducing potential temperature effects on coupled nitrification-denitrification.

Temperature dependence of denitrification and SOD was represented by a modified Arrhenius equation:

$R_{T}=R_{20} \cdot \theta^{T-20}$

With $R_{T}$ and $R_{20}$ representing the SOD or denitrification rate at temperature $T$ and $20^{\circ} \mathrm{C}$, respectively, and $\theta$ a dimensionless temperature coefficient (Kadlec and Reddy 2001) which was determined by fitting the model to the experimental data.

\section{Data Analysis}

One-way Analysis of Variance with Tukey HSD post-hoc tests were used to test for the effect of temperature on measured variables $(\alpha=0.05)$ after testing for normal distributions. Statistical analyses were performed using PASW Statistics 20 (IBM, New York, NY, USA).

\section{Results}

\section{Oxygen Microprofiles}

Measured oxygen microprofiles showed similar patterns for most microcosms (Fig. 2). Oxygen concentrations remained more or less constant in the upper part of the profile, indicating a mixed water column. This was followed by a sharp decrease of oxygen across the diffusive boundary layer (DBL) and in the top layer of the sediment, until anoxic conditions were reached. The oxygen penetration depth $(Z)$ varied between 1.4 and $5.0 \mathrm{~mm}$ (Table S1), and decreased with increasing temperature, 


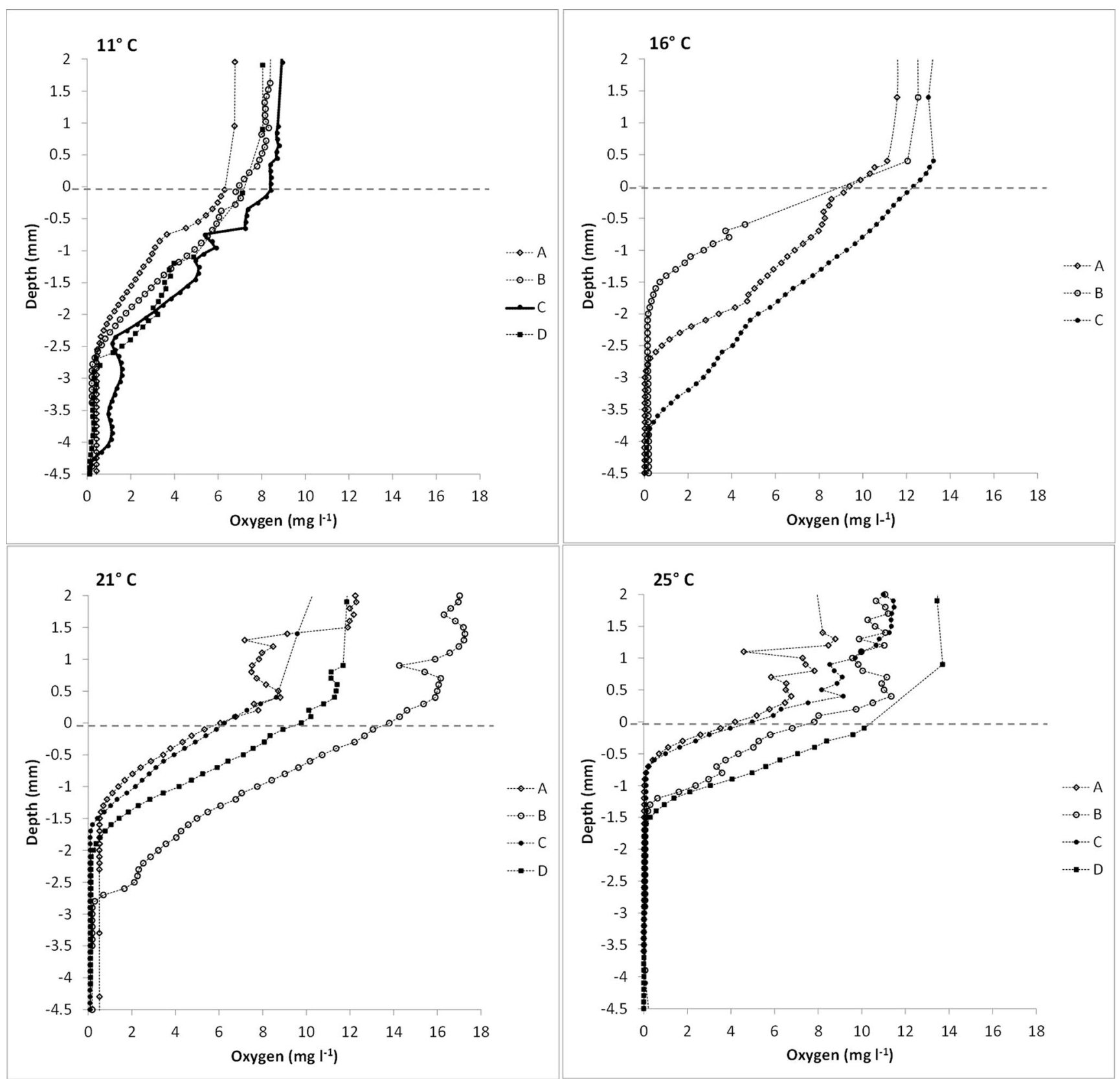

Fig. 2 Oxygen microprofiles measured in the microcosms at different temperatures

ranging from $4.12 \pm 0.66 \mathrm{~mm}$ at $11^{\circ} \mathrm{C}$, to $2.08 \pm 0.39 \mathrm{~mm}$ at $25{ }^{\circ} \mathrm{C}$ (Fig. $3 \mathrm{c}$ ). There was a significant difference in $\mathrm{Z}$ between $11,16,21{ }^{\circ} \mathrm{C}$ and $25{ }^{\circ} \mathrm{C}$.

The slopes of the oxygen profiles generally increased with temperature (Fig. 2), resulting in significantly different sediment oxygen demand (SOD) (Fig. 3B). Average SOD $(n=4)$ were $0.37,0.76,0.94$ and $1.53 \mathrm{~g} \mathrm{~m}^{-2} \mathrm{~d}^{-1}$ at $11,16,21$ and $25{ }^{\circ} \mathrm{C}$, respectively. Relating the SOD to the actual temperatures in the microcosms by fitting Eq. 2 resulted in a temperature coefficient $\theta$ of 1.09 $\left(\mathrm{SE}=0.017, \mathrm{R}^{2}=0.818\right)$ corresponding with a $\mathrm{Q}_{10}$-value of 2.4 .

\section{Denitrification}

Apparent denitrification rates ranged from 8.4 to $86 \mu \mathrm{mol} \mathrm{N}$ $\mathrm{m}^{-2} \mathrm{~h}^{-1}$ (Fig. 3, Table S1). A significant increase in denitrification was found with increasing temperature, ranging from $13.8 \pm 6.4 \mu \mathrm{mol} \mathrm{N} \mathrm{m}{ }^{-2} \mathrm{~h}^{-1}$ at $11^{\circ} \mathrm{C}$ to $62.8 \pm 15.6 \mu \mathrm{mol} \mathrm{N}$ $\mathrm{m}^{-2} \mathrm{~h}^{-1}$ at $25^{\circ} \mathrm{C}$ (Fig. 3A). Fitting Eq. 2 to the denitrification rates and the actual temperatures in the microcosms resulted in a temperature coefficient $\theta$ of $1.10\left(\mathrm{SE}=0.022, \mathrm{R}^{2}=0.705\right)$. This implies that with one degree warming denitrification rates increased $10 \%$, corresponding to a $\mathrm{Q}_{10}$-value of 2.6. Denitrification rates show a significant positive increase with 
A

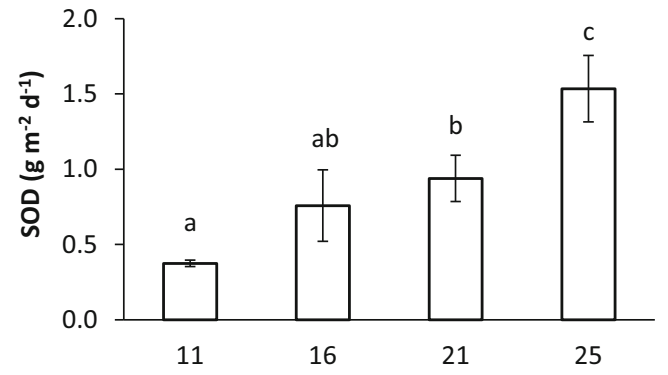

B

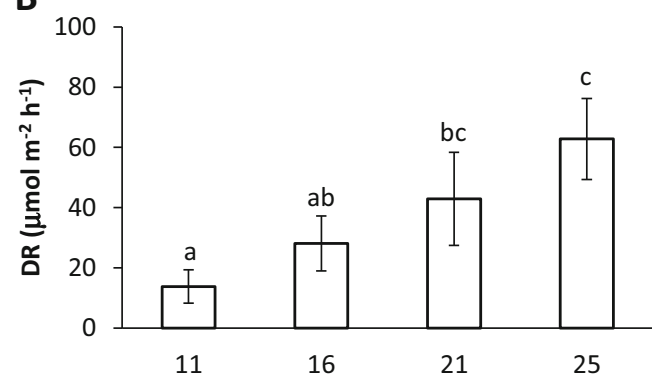

C

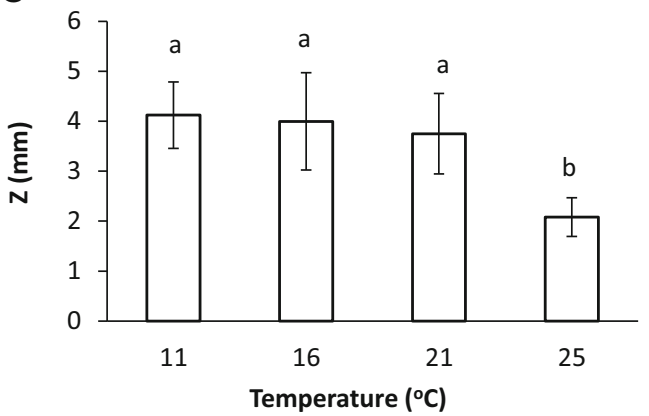

Fig. 3 Oxygen flux into the sediment (SOD, panel A), denitrification rate $(\mathrm{DR}$, panel $\mathbf{B})$ and oxygen penetration depth $(Z$, panel $\mathbf{C})$ (mean $\pm \mathrm{SD}$, $n=4 ; n=3$ for $\left.15^{\circ} \mathrm{C}\right)$. Letters indicate significant differences between treatments $(\alpha=.05)$

rising sediment oxygen demand $\left(\mathrm{R}^{2}=0.70, P<0.001\right.$, Fig. $4 a)$, and significant negative relationship with oxygen penetration depth $\left(\mathrm{Z}, \mathrm{R}^{2}=0.60, P<0.01\right.$, Fig. $\left.4 \mathrm{~b}\right)$.

When comparing the ratios of the different isotopic $\mathrm{N}_{2}-$ gasses we found that most of the produced gas was ${ }^{30} \mathrm{~N}_{2}$, between 88 and $100 \%$, with a lower share at higher temperatures (fig S1), indicating that most of the $\mathrm{N}_{2}$ was derived from the added ${ }^{15} \mathrm{NO}_{3}$ and not from nitrification or anammox of ${ }^{14} \mathrm{NH}_{4} / \mathrm{NO}_{2}$ From these results we conclude that the relative contribution of coupled nitrification-denitrification and potentially anammox to total $\mathrm{N}_{2}$-production accounted only for 0 to $12 \%$, and increased with warming.

\section{Discussion}

In this study we tested the effects of warming on sediment oxygen dynamics $(S O D, Z)$ and denitrification rates in drainage ditch sediments. We found that oxygen penetration depth a

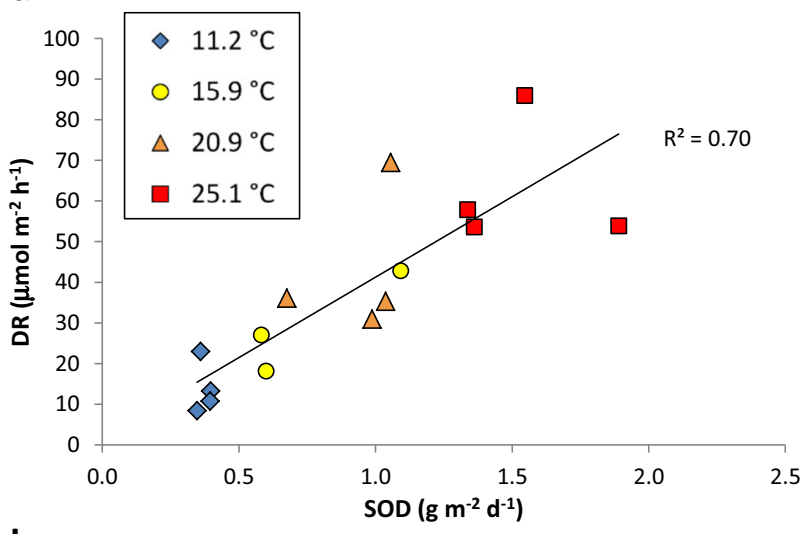

b

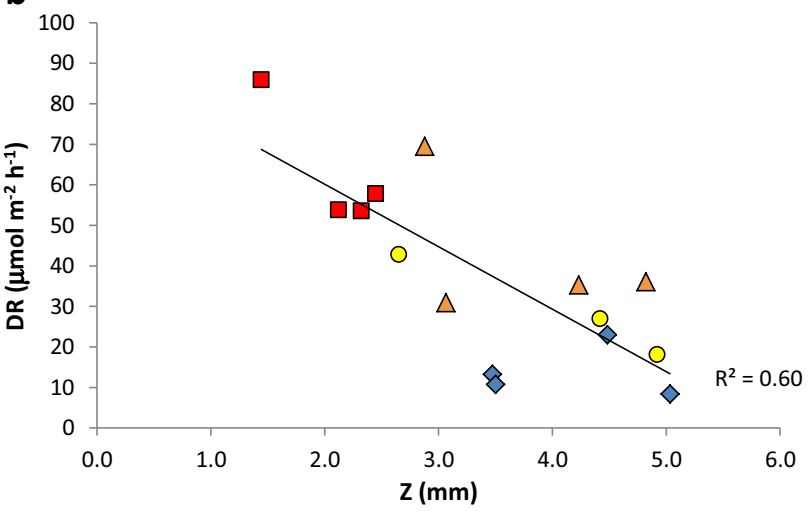

C

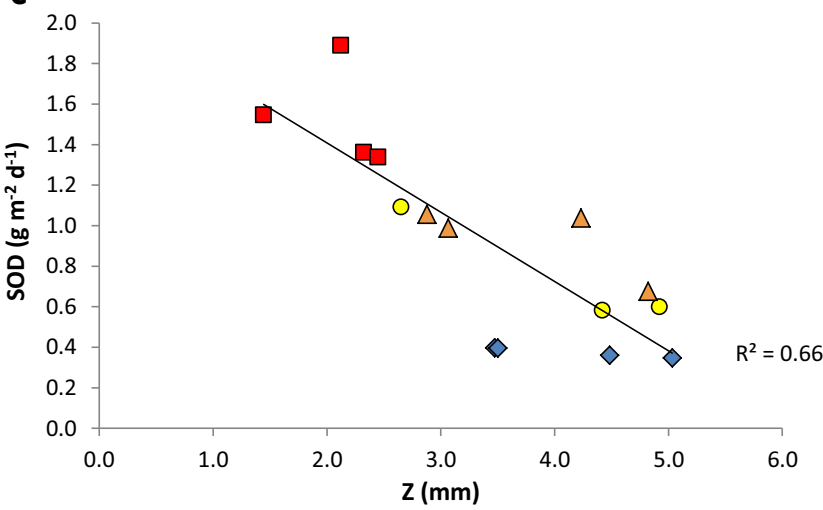

Fig. 4 Relations between sediment oxygen demand (SOD) and denitrification (panel a), oxygen penetration depth $(Z)$ and denitrification (panel b) and oxygen penetration depth and sediment oxygen demand (panel c), each dot represents a unique microcosm, warmer colours indicate higher temperatures $\left(\right.$ blue $=11$, yellow $=16$, orange $=21$, red $\left.=25^{\circ} \mathrm{C}\right)$

decreases with warming, related to enhanced SOD, which is in agreement with previous findings in marine sediments (Hancke and Glud 2004), caused by increased respiration activity at higher temperatures (Hancke and Glud 2004; Allen et al. 2005). Oxygen fluxes into the sediment are higher than those reported by other studies using microprofiles (Kim and Kim 2007; Hartnett et al. 2008). This can be explained by the sediments' characteristics and incubation procedure. Our sediments originated from freshwater ditches and contained about 
$8 \%$ organic matter, whereas those tested in previous studies were marine sediments, and contained less than $1 \%$ OM, leading to different biogeochemical properties and less oxygen consumption due to organic matter degradation. On the other hand, our oxygen fluxes were lower than reported by Hancke and Glud (2004), which can be explained by their measurements being in the dark with a strong influence of benthic microphyte respiration, whereas our measurements were conducted in light conditions. The microprofiles measured in our study indicate some photosynthesis in the water column, but within the sediment light availability is low, and we did not find evidence of benthic photosynthesis. Temperature dependence of $\operatorname{SOD}\left(\mathrm{Q}_{10}=2.4\right)$ is well in range with reported temperature dependences of degradation and respiration (Allen et al. 2005; Bouletreau et al. 2012).

In lakes and coastal sediments, warming has been found to lead to shifts from phototrophic to heterotrophic communities and overall higher mineralization, resulting in higher $\mathrm{CO}_{2}$ emission and less carbon burial (Hancke and Glud 2004; Gudasz et al. 2010). The increase of SOD and decrease of $Z$ with warming in our study also point at increased mineralization relative to carbon sequestering photosynthesis, indicating potentially greater $\mathrm{CO}_{2}$ fluxes from agricultural drainage ditches at higher temperatures. So far, when calculating regional greenhouse gas budgets, these water bodies have hardly been accounted for, although their total surface area within lowland catchment areas such as the Netherlands approximates that of shallow lakes or rivers.

\section{Denitrification}

The observed denitrification rates compare well to those previously reported, which are typically in the range of 10 to $500 \mu \mathrm{mol} \mathrm{N} \mathrm{m}{ }^{-2} \mathrm{~h}^{-1}$ (Seitzinger 1988; Christensen et al. 1990; Pina-Ochoa and Alvarez-Cobelas 2006; Mulholland et al. 2008; Veraart et al. 2011). However, comparisons between denitrification studies using different approaches should be treated with caution, for example, our methodology may underestimate rates compared to those using the Isotope Pairing Technique in sediment slurries. Still, we believe the set-up used in this study allows for investigating integrated temperature effects, as oxygen concentration and sediment nitrogen diffusion remained un-manipulated, and were left to respond to temperature as well. Denitrification rates increased with warming; the strength of the temperature response found in this study is lower $\left(\theta=1.10 ; \mathrm{Q}_{10}=2.6\right)$ than those observed for other drainage ditches, but comparable to values measured in wetlands (Kadlec and Reddy 2001). The weaker temperature effect indicates that other drivers besides temperature are of importance in controlling denitrification rates. This corroborates the findings of Brin et al. (2015) and Hanke et al. (2015), who both showed that availability of organic carbon is another key determinant controlling denitrification and its response to warming.

In our experiment nitrate concentrations were set at $1 \mathrm{mg} \mathrm{N}$ $1^{-1}$ at the start of the denitrification measurements. Under these conditions nitrate from the water just above the sediment is expected to be the dominant source of nitrate for denitrification (Seitzinger et al. 2006). Interestingly, although $\mathrm{NH}_{4}$ concentrations were low in all microcosms $(<0.06 \mathrm{mg} \mathrm{NH} 4-\mathrm{N}$ $1^{-1}$ ), the results suggest a small contribution of couplednitrification and potential for $\mathrm{N}_{2}$ produced by anammox, only in the 20 and $25^{\circ} \mathrm{C}$ microcosms. Ammonium needed for these processes can be derived from mineralization of organic $\mathrm{N}$ (Seitzinger et al. 1993; Laursen and Seitzinger 2004), and may indicate higher nitrogen mineralization at higher temperatures.

Microbial populations change with warming. For example, in enrichment bioreactors which contained communities derived from marine sediments, warming resulted in changed denitrification activity and community shifts, from a community where fermenters and organisms capable of nitrous oxide reduction were the dominant organic matter degraders at 10 degrees, to a system dominated by denitrifying populations, performing the complete denitrification pathway, at 25 degrees (Hanke et al. 2015). Thus, Hanke et al. (2015) show that temperature effects on denitrification rates are not only controlled by oxygen, but also by organic carbon, driven by changed interactions between fermenting and denitrifying bacteria. Effects of warming may also depend on the successional stage of microbial communities, as was observed in freshwater biofilms (Rysgaard et al. 1994), in which young biofilms showed increased denitrification rates with warming, whereas denitrification rates in older biofilms decreased. Because our measurements were performed within $48 \mathrm{~h}$ of incubation at a certain temperature, our results only reflect short-term temperature effects. They do not capture longterm changes in microbial community composition and associated biogeochemical effects (Wallenstein et al. 2006), but will nonetheless reflect effects acting on fast physicalchemical and enzymatic processes. Thus, there remains a need for long-term studies in ditches and wetlands, to better understand effects of warming and altered $\mathrm{N}$-influx on the interplay of oxygen and nitrogen dynamics, and the underlying changes in microbial community structure and function. Studies on effects of prolonged warming and altered $\mathrm{N}$-influx on greenhouse gas emission will be especially relevant in this respect, to facilitate improvement of regional greenhouse gas budgets.

\section{Conclusions}

Temperature strongly affected sediment oxygen dynamics and denitrification rates in drainage ditch sediments. Warming led to higher sediment oxygen demand and shallower oxygen 
penetration into the sediment. Denitrification rates increased exponentially with temperature, and were strongly related to both sediment oxygen demand and penetration depth. Our results show how different physical, chemical and microbial processes interact to change oxygen fluxes and denitrification under different warming regimes. Since many other processes in the sediment are regulated by oxygen availability the observed mechanisms are likely to affect other biogeochemical cycles (i.e. phosphorus, iron and sulphur) in a similar manner, which should be taken into account when predicting temperature effects on freshwater ecosystems.

Acknowledgements Authors thank Frits Gillissen for his valuable assistance in the experiments. AV was funded by the Dutch association for applied freshwater research (STOWA) and 14 Dutch water authorities as part of the PLONS-project.

Author Contributions Conceived and designed the experiments: AV CO JdK. Performed the experiments: AV CO. Analyzed the data: JdK AV CO CJJ. Wrote the paper: JdK AV CO.

Open Access This article is distributed under the terms of the Creative Commons Attribution 4.0 International License (http:// creativecommons.org/licenses/by/4.0/), which permits unrestricted use, distribution, and reproduction in any medium, provided you give appropriate credit to the original author(s) and the source, provide a link to the Creative Commons license, and indicate if changes were made.

\section{References}

Allen A, Gillooly J, Brown J (2005) Linking the global carbon cycle to individual metabolism. Functional Ecology 19:202-213

An SM, Gardner WS, Kana T (2001) Simultaneous measurement of denitrification and nitrogen fixation using isotope pairing with membrane inlet mass spectrometry analysis. Applied and Environmental Microbiology 67:1171-1178

Avnimelech Y, Ritvo G, Meijer LE, Kochba M (2001) Water content, organic carbon and dry bulk density in flooded sediments. Aquacultural Engineering 25:25-33

Bonnett SA, Blackwell M, Leah R, Cook V, O'Connor M, Maltby E (2013) Temperature response of denitrification rate and greenhouse gas production in agricultural river marginal wetland soils. Geobiology 11:252-267

Bouletreau S, Salvo E, Lyautey E, Mastrorillo S, Garabetian F (2012) Temperature dependence of denitrification in phototrophic river biofilms. Science of the Total Environment 416:323-328

Brin LD, Giblin AE, Rich JJ (2015) Effects of experimental warming and carbon addition on nitrate reduction and respiration in coastal sediments. Biogeochemistry 125:81-95

Burgin AJ, Hamilton SK, Jones SE, Lennon JT (2012) Denitrification by sulfur-oxidizing bacteria in a eutrophic lake. Aquatic Microbial Ecology 66:283-293

Christensen PB, Nielsen LP, Sorensen J, Revsbech NP (1990) Denitrification in nitrate-rich streams - diurnal and seasonalvariation related to benthic oxygen-metabolism. Limnology and Oceanography 35:640-651

Dalsgaard T (2000) Protocol handbook for NICE-nitrogen cycling in estuaries. National Environmental Research Institute, Copenhagen

de Klein JJM (2008) From Ditch to Delta, nutrient retention in running waters. PhD-thesis, Wageningen University, The Netherlands de Klein JJM, Koelmans AA (2011) Quantifying seasonal export and retention of nutrients in West European lowland rivers at catchment scale. Hydrological Processes 25:2102-2111

Elberling B, Damgaard LR (2001) Microscale measurements of oxygen diffusion and consumption in subaqueous sulfide tailings. Geochimica et Cosmochimica Acta 65:1897-1905

Erisman JW, Galloway JN, Seitzinger S, Bleeker A, Dise NB, Petrescu AR, Leach AM, de Vries W (2013) Consequences of human modification of the global nitrogen cycle. Philosophical Transactions of the Royal Society of London B: Biological Sciences 368:20130116

Ettwig KF, Butler MK, Le Paslier D, Pelletier E, Mangenot S, Kuypers MM, Schreiber F, Dutilh BE, Zedelius J, de Beer D (2010) Nitritedriven anaerobic methane oxidation by oxygenic bacteria. Nature 464:543-548

Gudasz C, Bastviken D, Steger K, Premke K, Sobek S, Tranvik LJ (2010) Temperature-controlled organic carbon mineralization in lake sediments. Nature 466:478-481

Han P, Bartels DM (1996) Temperature dependence of oxygen diffusion in H2O and D2O. The Journal of Physical Chemistry 100:55975602

Hancke K, Glud RN (2004) Temperature effects on respiration and photosynthesis in three diatom-dominated benthic communities. Aquatic Microbial Ecology 37:265-281

Hanke A, Berg J, Hargesheimer T, Tegetmeyer HE, Sharp CE, Strous M (2015) Selective pressure of temperature on competition and crossfeeding within denitrifying and fermentative microbial communities. Frontiers in Microbiology 6:1461

Hartnett H, Boehme S, Thomas C, DeMaster D, Smith C (2008) Benthic oxygen fluxes and denitrification rates from high-resolution porewater profiles from the Western Antarctic Peninsula continental shelf. Deep-Sea Research Part Ii-Topical Studies in Oceanography $55: 2415-2424$

Herzon I, Helenius J (2008) Agricultural drainage ditches, their biological importance and functioning. Biological Conservation 141:11711183

IPCC (2014) Climate change 2013: the physical science basis: working group $\mathrm{i}$ contribution to the fifth assessment report of the Intergovernmental panel on climate change. Cambridge University Press, Cambridge

Kadlec RH, Reddy KR (2001) Temperature effects in treatment wetlands. Water Environment Research 73:543-557

Kana TM, Darkangelo C, Hunt MD, Oldham JB, Bennett GE, Cornwell JC (1994) Membrane inlet mass-spectrometer for rapid highprecision determination of $\mathrm{N} 2, \mathrm{O} 2$, and $\mathrm{Ar}$ in environmental water samples. Analytical Chemistry 66:4166-4170

Kim KH, Kim D (2007) Seasonal and spatial variability of sediment oxygen fluxes in the Beobsan intertidal flat of Taean Bay, midwestern Korean Peninsula. Geosciences Journal 11:323-329

Knowles R (1982) Denitrification. Microbiol Rev 46:43-70

Laursen AE, Seitzinger SP (2004) Diurnal patterns of denitrification, oxygen consumption and nitrous oxide production in rivers measured at the whole-reach scale. Freshwater Biology 49:1448-1458

Mulholland PJ, Helton AM, Poole GC, Hall RO, Hamilton SK, Peterson BJ, Tank JL, Ashkenas LR, Cooper LW, Dahm CN, Dodds WK, Findlay SEG, Gregory SV, Grimm NB, Johnson SL, McDowell WH, Meyer JL, Valett HM, Webster JR, Arango CP, Beaulieu JJ, Bernot MJ, Burgin AJ, Crenshaw CL, Johnson LT, Niederlehner BR, O'Brien JM, Potter JD, Sheibley RW, Sobota DJ, Thomas SM (2008) Stream denitrification across biomes and its response to anthropogenic nitrate loading. Nature 452:202-U246

Nielsen LP (1992) Denitrification in sediment determined from nitrogen isotope pairing. FEMS Microbiology Ecology 86:357-362

Pina-Ochoa E, Alvarez-Cobelas M (2006) Denitrification in aquatic environments: a cross-system analysis. Biogeochemistry 81:111-130

Risgaard-Pedersen N, Rysgaard S, Nielsen LP, Revsbech NP (1994) Diurnal-variation of denitrification and nitrification in sediments 
colonized by benthic microphytes. Limnology and Oceanography 39:573-579

Risgaard-Petersen N, Nielsen LP, Rysgaard S, Dalsgaard T, Meyer RL (2003) Application of the isotope pairing technique in sediments where anammox and denitrification coexist. Limnology and Oceanography: Methods 1:63-73

Rysgaard S, Risgaardpetersen N, Sloth NP, Jensen K, Nielsen LP (1994) Oxygen Regulation of Nitrification and Denitrification in Sediments. Limnology and Oceanography 39:1643-1652

Saunders D, Kalff J (2001) Nitrogen retention in wetlands, lakes and rivers. Hydrobiologia 443:205-212

Schrier-Uijl A, Veraart A, Leffelaar P, Berendse F, Veenendaal E (2011) Release of $\mathrm{CO} 2$ and $\mathrm{CH} 4$ from lakes and drainage ditches in temperate wetlands. Biogeochemistry 102:265-279

Seitzinger S, Harrison JA, Bohlke JK, Bouwman AF, Lowrance R, Peterson B, Tobias C, Van Drecht G (2006) Denitrification across landscapes and waterscapes: a synthesis. Ecological Applications 16:2064-2090

Seitzinger SP (1988) Denitrification in fresh-water and coastal marine ecosystems - ecological and geochemical significance. Limnology and Oceanography 33:702-724

Seitzinger SP (1994) Linkages between organic-matter mineralization and denitrification in 8 riparian wetlands. Biogeochemistry 25:19 39

Seitzinger SP, Nielsen LP, Caffrey J, Christensen PB (1993) denitrification measurements in aquatic sediments - a comparison of 3 methods. Biogeochemistry 23:147-167
Smart RM, Barko JW (1985) Laboratory culture of submersed freshwater macrophytes on natural sediments. Aquatic Botany 21:251263

Steffen W, Richardson K, Rockström J, Cornell SE, Fetzer I, Bennett EM, Biggs R, Carpenter SR, de Vries W, de Wit CA (2015) Planetary boundaries: guiding human development on a changing planet. Science 347:1259855

Stein LY, Klotz MG (2016) The nitrogen cycle. Current Biology 26:R94 R98

Veraart AJ (2012) Denitrification in ditches, streams and shallow lakes. Wageningen University, Wageningen

Veraart AJ, de Klein JJM, Scheffer M (2011) Warming can boost denitrification disproportionately due to altered oxygen dynamics. Plos One 6:e18508

Veraart AJ, Dimitrov MR, Schrier-Uijl AP, Smidt H, de Klein JJM (2016) Abundance, activity and community structure of denitrifiers in drainage ditches in relation to sediment characteristics, vegetation and land-use. Ecosystems:1-16

Wallenstein MD, Myrold DD, Firestone M, Voytek M (2006) Environmental controls on denitrifying communities and denitrification rates: insights from molecular methods. Ecological Applications 16:2143-2152

Yvon-Durocher G, Jones JI, Trimmer M, Woodward G, Montoya JM (2010) Warming alters the metabolic balance of ecosystems. Philosophical Transactions of the Royal Society of London B: Biological Sciences 365:2117-2126 